pathy would impair their ability to use the BM Test colour comparison scale, this has not proved to be the case in practice. Although the value of home monitoring of glucose concentrations has been questioned, ${ }^{13}$ the vast majority of those likely to benefit from the technique, especially the adolescent, pregnant women, and diabetics who cannot rely on urine tests, are unlikely to have any difficulty due to defective colour vision. All patients introduced to the technique should be assessed carefully before relying on their observations, particularly if they are elderly, but routine testing of colour vision seems unnecessary.

Requests for reprints should be addressed to Dr C M Kesson, Department of Medicine, Southern General Hospital, Glasgow G51 $4 \mathrm{TF}$.

\author{
References \\ ${ }^{1}$ Watkins PJ. Insulin infusion systems, diabetic control and microvascular \\ complications. Br Med f 1980;280:350-2.
}

${ }^{2}$ Knowles HC. Diabetes mellitus: theory and practice. New York: McGrawHill, 1971.

${ }^{3}$ Malone JI, Rosenbloom AL, Grgic A, Weber FT. The role of urine sugar in diabetic management. Am $\mathcal{F}$ Dis Child 1976;130:1324-7.

${ }^{4}$ Gabbay KH, Hasty K, Breslow JL, Ellison RC, Bunn HF, Gallop PM. Glycosylated haemoglobins and long-term blood glucose control in diabetes mellitus. F Clin Endocrinol Metab 1977;44:859-64.

${ }^{5}$ Sonksen PH, Judd SL, Lowry D. Home monitoring of blood glucose. Lancet 1978;i:729-32.

${ }^{6}$ Walford S, Gale EAM, Allison SP, Tattersall RB. Self-monitoring of blood glucose. Lancet $1978 ; \mathrm{i}: 732-5$.

${ }^{7}$ Borthwick LJ, Ross IS. Performance of blood glucose meters. Lancet $1979 ; \mathrm{i}: 924$.

${ }^{8}$ Lawson PM, Kesson CM, Ireland JT. Performance of blood glucose strips. Lancet 1979 ;ii:742.

9 Thompson DG, Howarth F, Levy IS. Colour blindness, a hazard to diabetics. Lancet 1978; ; 44 .

${ }^{10}$ Thomson DG, Howarth F, Taylor H, Levy IS. Defective colour vision in diabetes: a hazard to management. $B r \operatorname{Med} \mathcal{F} 1979 ; \mathrm{i}: 859-60$.

11 Foulds WS. Medical ophthalmology. London: Chapman and Hall, 1976:33.

12 Farnsworth D. The Farnsworth-Munsell 100-hue test. Baltimore: Munsell Color Company, 1957.

${ }^{13}$ Anonymous. Home blood-glucose monitoring: revolution, revelation or rip-off ? Lancet 1980;ii:187-8.

(Accepted 27 August 1980)

\title{
Effect of treatment of hyperlipidaemia on haemostatic variables
}

\author{
R S ELKELES, R CHAKRABARTI, MARGUERITE VICKERS, YVONNE STIRLING, T W MEADE
}

\section{Summary and conclusions}

The haemostatic function of 11 men with hyperlipidaemia was measured before and after they were treated with a carbohydrate-reduced, fat-modified diet. After treatment, which significantly reduced serum triglyceride and cholesterol concentrations, they showed a significant fall in mean levels of clotting factors VII, VIII, and $X$ and a rise in fibrinolytic activity.

These findings suggest that haemostatic function may be important in the pathogenesis of ischaemic heart disease.

\section{Introduction}

The Northwick Park Heart Study has produced evidence of an association between high concentrations of factor VII, factor VIII, and fibrinogen and an increased risk of later cardiovascular death. ${ }^{1}$ We describe here the changes in these and other haemostatic variables in men who were treated for hyperlipidaemia.

St Mary's Hospital, London W2 1NY

R S ELKELES, MD, MRCP, consultant physician

MRC Epidemiology and Medical Care Unit, Northwick Park Hospital, Harrow, Middlesex HA1 3UJ

R CHAKRABARTI, MB, MRCPATH, member of scientific staff

MARGUERITE VICKERS, BSC, technician

YVONNE STIRLING, FIMLS, chief medical laboratory scientific officer

T W MEADE, BM, FRCP, director

\section{Patients and methods}

Eleven men were studied. Nine were participants in the Northwick Part Heart Study referred for further investigation of hyperlipidaemia found at entry to the study; three of these men were also found to have chemical diabetes on oral glucose tolerance tests. Two known maturity-onset diabetics were also studied. The mean age of the 11 men was 50 years (range 31-65), and their mean body weight before treatment was $76 \cdot 3 \mathrm{~kg}$.

All the men were treated with a carbohydrate-reduced, fat-modified diet. $^{2}$ The diets contained 120-150 $\mathrm{g}$ carbohydrate and 5.0-6.3 MJ (1200-1500 kcal) a day, depending partly on previous intake. The daily cholesterol intake was about $300 \mathrm{mg}$. The ratio of polyunsaturated to saturated fats was $1 \cdot 4: 1$. Two men also received clofibrate $1 \mathrm{~g}$ twice daily. There was no evidence of excess alcohol consumption in any of the men, and they did not change their smoking habits during the study.

Biochemical and haemostatic tests were performed before and after treatment, which lasted a mean of three months (range 1-5). Venous blood was taken through an indwelling cannula between 9 and 10 am after an overnight fast. Serum triglyceride, cholesterol, and blood glucose concentrations were measured by standard enzymatic techniques; data on individual lipoprotein fractions in eight of the men have already been published. ${ }^{3}$ Fibrinogen and clotting or biological antithrombin activity levels of factors II, V, VII, VIII (denoted VIII $_{c}$ ), and X; III ; factor VIII-related antigen (denoted VIII ${ }_{a}$ ); and fibrinolytic activity were measured by methods described elsewhere. ${ }^{45}$ Clotting-factor assays were all carried out against the same standard and values were expressed as percentages of this standard. Fibrinolytic activity was expressed as 100/lysis time in hours.

Results before and after treatment were compared using Student's paired $t$ test (two-tailed).

\section{Results}

The findings are shown in the table. There was a sharp reduction in the mean concentration of fasting serum triglycerides and there were also significant reductions in total serum cholesterol and fasting 
TABLE I-Mean $( \pm S D)$ body weight and biochemical and haemostatic values in 11 men before and after treatment

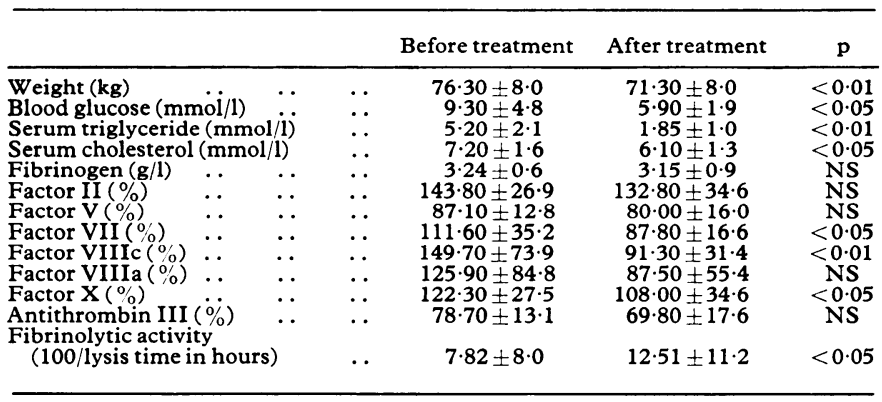

The clotting factor values in this table are based on the use of one standard; they are not directly comparable with values in other reports on the Northwick Park NS = Not significant.

blood glucose concentrations. All clotting factor levels fell and fibrinolytic activity increased, the changes being significant for factors VII, VIII ${ }_{c}$, and $\mathrm{X}$ and fibrinolytic activity. There was a mean weight loss of $5 \mathrm{~kg}$.

\section{Discussion}

In a study of 20 patients with hypertriglyceridaemia treated with phenformin and stanozolol there was a consistent reduction in serum triglyceride concentrations and an increase in fibrinolytic activity, but no other haemostatic variables were studied. ${ }^{6}$ Hypertriglyceridaemia was also the most obvious abnormality in the men in our study. The relation between serum triglyceride concentrations and the incidence of ischaemic heart disease is less clear than in the case of serum cholesterol. Two prospective studies have found that triglyceride concentrations make an independent contribution to the risk of ischaemic heart disease, ${ }^{78}$ while two have not established this. ${ }^{910}$ The 11 men we studied also had other metabolic abnormalities which are associated with an increased risk of ischaemic heart disease. Besides the very obvious fall in triglyceride concentrations, the treatment was followed by a significant fall in mean serum cholesterol and mean blood glucose concentrations. Our study was not controlled by an untreated group and regression to the mean cannot be excluded as a partial explanation of the results. But the changes in the biochemical variables on the basis of which the men were selected for study were accompanied by changes in haemostatic function. These findings, together with the early prospective results of the Northwick Park Heart Study, ${ }^{1}$ are compatible with the view that haemostatic function may be important in the pathogenesis of ischaemic heart disease.

Requests for reprints should be addressed to Dr R S Elkeles, St Mary's Hospital, Praed Street, London W2 1NY.

\section{References}

1 Meade TW, Brozovic M, Chakrabarti R, et al. Haemostatic function and cardiovascular death: early results of a prospective study. Lancet 1980 ; i:1050-3.

2 Tabaqchali S, Chait A, Harrison R, Lewis B. Experience with simplified scheme of treatment of hyperlipidaemia. Br Med F 1974 ;iii:377-80.

3 Elkeles RS. Effect of treatment of hypertriglyceridaemia on high and low density lipoprotein cholesterol concentration. Lancet 1979;i:980-1.

4 Meade TW, North WRS. Population based distribution of haemostatic variables. Br Med Bull 1977;33:283-8.

5 Meade TW, Brozovic M, Chakrabarti R, Howarth DJ, North WRS, Stirling Y. An epidemiological study of the haemostatic and other effects of oral contraceptives. Br $\mathcal{F}$ Haematol 1976;34:353-64.

${ }^{6}$ Ciswicka-Szajderman M, Berent H, Rymszewski Z. The effect of combined treatment with phenformin and stanozolol on blood lipids and fibrinolytic activity in patients with hypertriglyceridaemia. Atherosclerosis $1974 ; 19: 153-9$.

7 Pelkonen R, Nikkila EA, Koskinen S, Pentinen V, Sana S. Association of serum lipids and obesity with cardiovascular mortality. $\mathrm{Br} \mathrm{Med} \mathcal{F} 1977$; ii :1185-7.

${ }^{8}$ Carlson LA, Bottiger LE, Ahfeldt PE. Risk factors for myocardial infarction in the Stockholm prospective study. Acta Med Scand 1979; 206:351-60.

9 Kannel WB, Castelli WP, Gordon T, McNamara PM. Serum cholesterol, lipoproteins, and the risk of coronary heart disease. Ann Intern Med $1971 ; 74: 1-12$.

10 Wilhemsen L, Wedel H, Tibblin G. Multivariate analysis of risk factors for coronary heart disease. Circulation 1973;48:950-8.

(Accepted 27 August 1980)

\section{SHORT REPORTS}

\section{Motor neuropathy associated with cimetidine}

Reported side effects of cimetidine include arrhythmias, ${ }^{1}$ thrombocytopenia, ${ }^{2}$ and coma. ${ }^{3}$ Peripheral neuropathy, however, has apparently not been described. We report two closely similar cases of motor neuropathy that may have been caused by cimetidine.

\section{Case reports}

Case 1-A 44-year-old woman admitted to hospital in status asthmaticus failed to respond to conservative management for 24 hours, and intermittent positive-pressure ventilation was therefore instituted. Over the next five days she improved, treatment including intravenous salbutamol, hydrocortisone $1 \mathrm{~g}$ daily, lorazepam, pancuronium, and phenoperidine as required, and cimetidine $200 \mathrm{mg}$ six-hourly as prophylaxis against peptic ulceration. Intermittent positive-pressure ventilation was stopped and treatment changed to oral prednisolone and nebulised salbutamol only. She had developed severe weakness in all limbs, which was most pronounced distally and associated with areflexia. Sensory examination showed nothing abnormal. Within 48 hours motor function began to return, and within four weeks recovery was almost complete. During maximal weakness the cerebrospinal fluid contained no cells, and the protein concentration was $0.3 \mathrm{~g} / \mathrm{l}$. There was no detectable increase in serum antibody titre to $\mathrm{Myco}$ plasma, common respiratory viruses, or Coxsackie B viruses.
Case 2-This 29-year-old woman in status asthmaticus failed to respond to conservative measures and began intermittent positive-pressure ventilation 36 hours after admission. Treatment was continued for nine days and included hydrocortisone $1 \mathrm{~g}$ daily, subcutaneous terbutaline $0.5 \mathrm{mg}$ sixhourly, nebulised salbutamol, and infusions of aminophylline and cotrimoxazole. Phenoperidine, pancuronium, and diazepam were used as necessary in conventional dosage to permit ventilation and for sedation. Eight days after beginning ventilation she vomited altered blood and was given cimetidine $200 \mathrm{mg}$ six-hourly to a total of seven doses. On stopping ventilation she was found to be weak, most pronounced distally (MRC grades $3-4$ ), and areflexic. Sensory findings were normal. Serum potassium and calcium concentrations were normal, as was creatine phosphokinase activity (53 IU/l; normal 5-100 IU/1). There was no rise in antibody titres to common respiratory viruses or Mycoplasma. Result of the heterophile antibody test was negative. Cerebrospinal fluid was of normal pressure and contained $0.3 \mathrm{~g}$ protein/1; no cells were detected, and findings on virus culture were negative. Nerve conduction velocities were normal but the evoked muscle action potential was dispersed and of low amplitude $(250 \mu \mathrm{V}$ in extensor hallucis brevis). Appearances on concentric needle electromyography-namely, fibrillation potentials, positive sharp waves, and bizarre high-frequency discharges with impaired recruitment-suggested axonal neuropathy. She recovered rapidly, with increase in strength within 48 hours, and recovered fully in eight weeks.

\section{Comment}

These patients presented with an exacerbation of longstanding asthma that did not respond to conservative treatment and necessitated 